\title{
MULTIDISCIPLINARY SURGICAL TREATMENT OF CLEAR-CELL RENAL CARCINOMA WITH INFERIOR VENA CAVA TUMOR THROMBUS LEVEL III AND IV: OUR EXPERIENCE DURING THE PAST DECADE
}

\author{
TVRTKO HUDOLIN ${ }^{1,2}$, VLADIMIR FERENČAK ${ }^{1}$, LUKA PENEZIĆ ${ }^{1}$, TONI ZEKULIĆ ${ }^{1}$, \\ TOMISLAV KULIŠ ${ }^{1,2}$, MARJAN MARIĆ ${ }_{\breve{1}}$, OLIVER PAVLOVIĆ ${ }^{3,4}$, AHMAD EL-SALEH $^{1}$, \\ NIKOLA KNEŽEVIĆ ${ }^{1,2}$, ELEONORA GOLUŽA ${ }^{2,5}$, BOJAN BIOČINA ${ }^{6}$ and ŽELJKO KAŠTELAN ${ }^{1,2}$ \\ ${ }^{1}$ Department of Urology, University Hospital Center Zagreb, Zagreb, Croatia; \\ ${ }^{2}$ University of Zagreb School of Medicine, Zagreb, Croatia; \\ ${ }^{3}$ Faculty of Medicine, University Josip Juraj Strossmayer, Osijek, Croatia; \\ ${ }^{4}$ Department of Urology, Osijek University Hospital Center, Osijek, Croatia; \\ ${ }^{5}$ Department of Anesthesiology, Reanimatology, and Intensive Medicine, \\ University Hospital Centre Zagreb, Zagreb, Croatia; \\ ${ }^{6}$ Department of Cardiac Surgery, School of Medicine, University of Zagreb, Zagreb, Croatia
}

\begin{abstract}
Summary
Patients with non-metastatic, stage T3 clear-cell renal cell cancer present a clinical challenge for urologists. The extent of tumor thrombus in inferior vena cava is the primary determinant of surgical procedure complexity. Level III and IV thrombi require the use of cardiopulmonary bypass and hypothermic arrest. Careful preoperative planning and a multidisciplinary approach are mandatory. In this paper, we report outcomes of 12 patients who were surgically treated in our center. The 29 months overall survival for all patients was $69 \%$, while three patients died during follow-up. Of nine surviving patients, six are currently disease-free, whereas three had disease progression. Our study showed that carefully selected patients with clear-cell renal cell carcinoma with inferior vena cava tumor thrombus level III and IV could be successfully treated with an aggressive surgical approach.
\end{abstract}

KEYWORDS: Renal Cell Carcinoma, Inferior Vena Cava, Venous Thrombosis, Radical Nephrectomy, Cardiopulmonary Bypass

\section{INTRODUCTION}

Clear-cell renal cell carcinoma (ccRCC) accounts for $3.5 \%$ of all adult neoplasms and has a high mortality rate causing $2.3 \%$ of cancer-related deaths, making it one of the deadliest urological cancers (1). Formation of inferior vena cava tumor thrombus (IVCTT) can be found in up to $10 \%$ of patients with ccRCC (2). With no distant metastases and after successful surgery, these patients

Corresponding author: Tomislav Kuliš, Department of Urology, University Hospital Center Zagreb, Kišpatićeva 12, 10000 Zagreb, Croatia.

e-mail:tkulis@kbc-zagreb.hr have a good prognosis with a 5-year overall survival of $47-63 \%$ (3-7). However, if left untreated, they have a poor prognosis with a median survival of $29 \%$ and one-year disease-specific survival of 5 months (8). Surgical procedures for the treatment of ccRCC with IVCTT are demanding and require careful planning and a multidisciplinary approach, but if performed successfully, they give patients the best chance of survival. Nevertheless, it is essential to determine the tumor thrombus level in the vena cava before surgery.

The 2017 tumor node metastases (TNM) classification is inadequate for final decision making since it lacks anatomical precision and defines 
only three levels of thrombus extension: T3a - into the renal vein or it is segmental (muscle-containing) branches, $\mathrm{T} 3 \mathrm{~b}$ - into the inferior vena cava (IVC) below diaphragm and T3c - into IVC above the diaphragm or invasion of the caval wall. The most widely used classification system of the thrombus extension is the Mayo 5-level classification: level 0 - into the renal vein only; level I - into the IVC but no more than $2 \mathrm{~cm}$ above the renal vein; level II - into the IVC $2 \mathrm{~cm}$ above the renal vein but not to the hepatic vein; level III - into the IVC above the hepatic vein but not to the diaphragm; and level IV - into the supradiaphragmatic IVC or right atrium (9). Levels III and IV are the most challenging and, in most cases, require the use of a cardiopulmonary bypass (CPB) with deep hypothermic circulatory arrest (DHCA). Intraoperative and postoperative complications such as myocardial infarction, cerebrovascular accident, congestive heart failure, pulmonary embolism, atelectasis, pneumonia, and thrombophlebitis occur in up to $30 \%$ of cases, and the 90-day mortality rate is $3-16 \%(10,11)$.

This paper aims to present our experience in treating cCRCC with level III and IV inferior vena cava tumor thrombi.

\section{MATERIALS AND METHODS}

In this single-center retrospective observational study, we analyzed archived patient's medical records. We report the demographic data, sur-

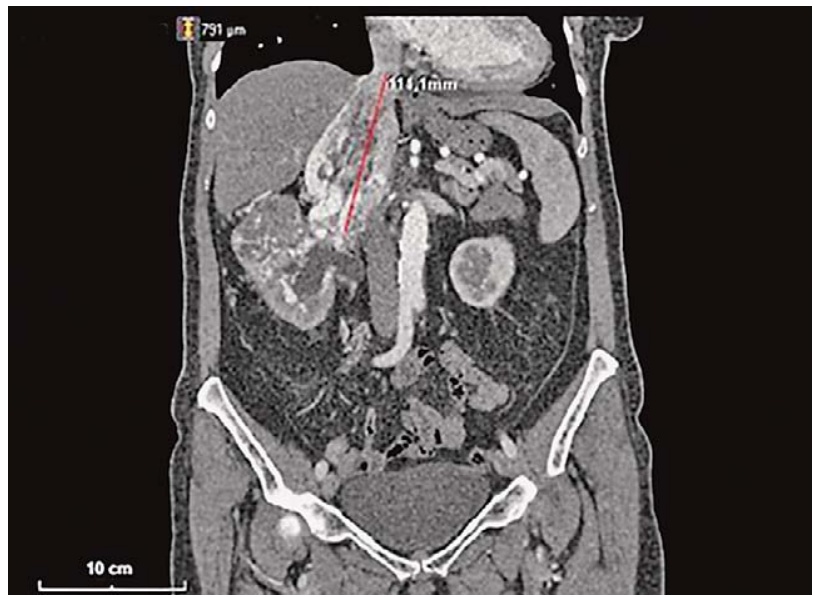

Figure 1. Large tumor thrombus in inferior vena cava on computerized tomography gical procedures, intraoperative and postoperative complications, final histological diagnosis, and overall survival using descriptive statistics. All patients underwent a thorough preoperative diagnostic workup. Radiologic staging and the determination of the upper extent of tumor thrombus in IVC was performed by contrast-enhanced computed tomography and/or magnetic resonance imaging (Figure 1). When indicated, echocardiography was performed to detect a thrombus extension in the right atrium.

The patients were presented on a multidisciplinary tumor board consisting of urologists, oncologists, radiologists, anesthesiologists, and cardiothoracic surgeons to determine the optimal individual treatment option. All patients signed informed consent.

\section{Surgical approach}

The operation can be divided into two parts, urological and cardiothoracic. First, a Chevron incision is made, and the colon mobilized, followed by detailed identification and preparation of all relevant anatomical structures. The renal artery should be ligated as soon as possible, while the right and the left renal vein and IVC should be exposed. Careful intraoperative assessment of thrombus extension is mandatory. Once all the veins have been prepared and secured for vascular control, the cardiothoracic part begins with a median sternotomy for the approach to the heart. The extracorporeal bypass is established, and hypothermia of $18^{\circ} \mathrm{C}$ induced, after which the cardiopulmonary arrest occurs. The cardiothoracic



Figure 2. Kidney with tumor and visible large tumor thrombus 


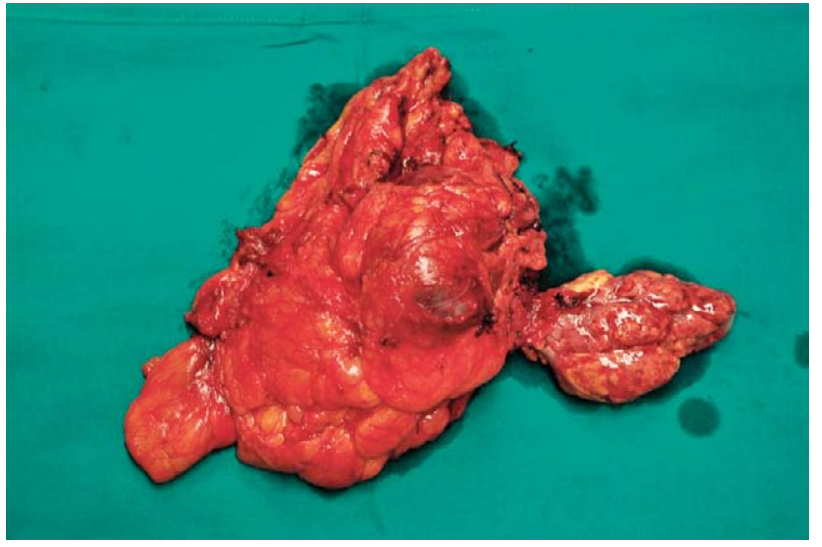

Figure 3. Kidney with tumor and large tumor thrombus after nephrectomy

surgeon's role is also to determine the supradiaphragmatic extent of the tumor thrombus and, when indicated, open the right atrium and assist in removing the thrombus by mobilizing it caudally. As the urological part of the procedure resumes, an IVC incision is made, and the tumor thrombus is extracted, the IVC is sutured, and the kidney with the tumor is removed, followed by heart rewarming and gaining spontaneous sinus rhythm after which the bypass is removed (Figures 2-3). The procedure ends with the placement of drainage and closure of the wounds.

\section{RESULTS}

Twelve patients with ccRCC and IVCTT were surgically treated from April 2011 to February 2020 in our center. Patients and tumor characteristics are shown in Table 1. Preoperatively, IVC tumor thrombus was classified as level III or level IV. Therefore all procedures were performed in collaboration with cardiothoracic surgeons. Eleven procedures included CPB with DHCA, and one procedure was performed without bypass because, after sternotomy, pericardiotomy, inspection, and palpation of the right atrium, the thrombus was not evident supradiafragmatically, so the procedure was completed only by abdominal approach.

There were no intraoperative or 90-day perioperative deaths. None of the patients had Clavien Dindo grade III or higher postoperative complications. Four Clavien Dindo grade II complications occurred: two patients had atrial fibrillation,
Table 1.

Patients and tumor characteristics

\begin{tabular}{|l|l|}
\hline Variable & Number (Percentage) \\
\hline Patients & $12(100 \%)$ \\
\hline Male & $4(33,3 \%)$ \\
\hline Female & $8(66,7 \%)$ \\
\hline Left side & $4(33,3 \%)$ \\
\hline Right side & $8(66,7 \%)$ \\
\hline & Median (IQ range) \\
\hline Age (years) & $63,5(54,5-70,25)$ \\
\hline Preoperative Mayo Classification & Number (Percentage) \\
\hline Level III & $4(33,3 \%)$ \\
\hline Level IV & $8(66,7 \%)$ \\
\hline
\end{tabular}

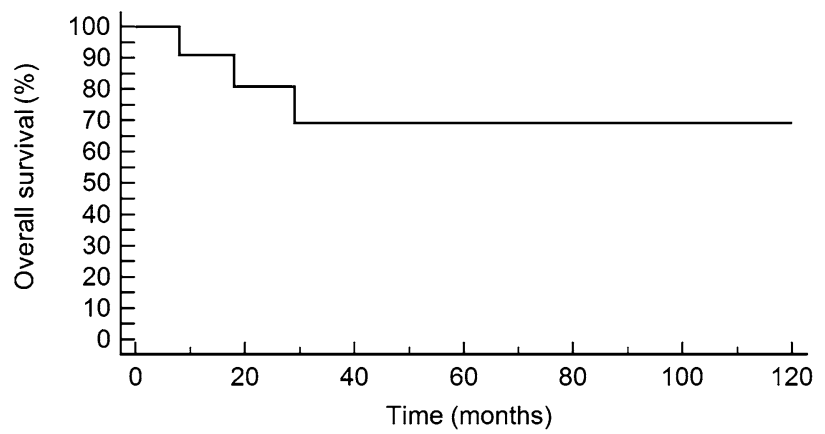

Figure 4. Overall survival curve for all operated patients

one patient had a pneumothorax and atrial fibrillation, and one patient had transitory lower limb ischemia. All these complications were managed conservatively. The median follow-up was 38 months (IQ range 16.75 - 66 months). Three patients died during follow up, two due to cardiovascular comorbidity and one due to disease progression. The 29 months overall survival for all patients was 69\% (Figure 4). Nine surviving patients undergo regular oncological follow-up. Six are disease-free, whereas three had disease progression, two are receiving first-line systematic treatment for pulmonary metastases (sunitinib and nivolumab), and one is on the second-line for hepatic metastases (nivolumab + axitinib). In our series, three patients had 5-years disease-free, and seven patients had 2-years disease-free survival.

\section{DISCUSSION}

Our study showed that patients with stage T3 ccRCC and IVCTT levels III and IV can be successfully treated with an aggressive surgical ap- 
proach. Although these patients pose a significant challenge for surgeons, anesthesiologists, and all the other surgical team members, radical and complete removal of the tumor and tumor thrombus seems to be the most important determinant of curative treatment. This demanding surgery has a high rate of severe perioperative and postoperative complications in up to $30 \%$ of cases. Patients with supradiaphragmatic IVCTT have 11fold higher postoperative complication rates when compared to patients with renal vein involvement only, with intraoperative bleeding and postoperative arrhythmias and secondary hemorrhage being the most common (10). Cardiopulmonary bypass with the deep hypothermic circulatory arrest was introduced in 1984 as a new method for the management of ccRCC with supradiaphragmatic IVCTT (14). Although incredibly beneficial for IVCTT surgery, the use of CPB and DHCA can produce platelet dysfunction and coagulopathy, thus facilitating bleeding in the postoperative period (15).

In our series, we had no significant intraoperative complications, and all postoperative complications were treated conservatively. Although we did not have intraoperative or perioperative mortality, the previously reported series showed a $3-16 \%$ mortality (9-13).

The association between the level of proximal venous thrombus and overall survival is still unclear. Some studies showed no association, while others identified IVC involvement as a negative prognostic factor (11). However, atrial involvement with tumor thrombus adds complexity to the procedure, increasing the probability of intraoperative morbidity and mortality. Since this type of surgery has considerable risks, the patient and his family must be informed about possible complications and adverse outcomes. Due to the complexity of cases with thrombus going from renal vein to right atrium, careful preoperative planning and a multidisciplinary approach are mandatory.

The use of optimal surgical techniques and collaboration between urologists, abdominal and cardiothoracic surgeons, radiologists, oncologists, and anesthesiologists is needed to achieve the best oncological results without risking the patient's safety.

Level I and II IVCTT can be managed with the IVC occlusion and can be resected without by- pass. For level III and IV thrombus, liver mobilization and dissection of IVC and the use of CPB and DHCA are usually needed for the complete removal of tumor thrombus and vascular stability of the patient. Since all of our patients had level III and IV IVCTT, we needed a cardiothoracic surgeon's support.

With advances in minimally invasive surgery, laparoscopic and robotic nephrectomy with thrombectomy were proven feasible and safe for carefully selected patients in experienced centers $(10,16)$. Wang et al. reported a series of 13 patients with level III and IV tumor thrombi that have been performed successfully using a combination of robotic surgery, thoracoscopy-assisted thrombectomy, and CPB (16). Currently, there is an active phase III study investigating neoadjuvant therapy's potential effect with nivolumab for patients with high-risk, non-metastatic RCC (17). The PROSPER study's primary goal is to improve recurrence-free survival, but it would be interesting to evaluate the impact of neoadjuvant therapy in the reduction of tumor thrombus, thus facilitating the surgical procedure.

In conclusion, surgical treatment of advanced ccRCC involving the IVC is feasible with acceptable morbidity and mortality in carefully selected patients. This procedure should be performed in experienced centers and with a multidisciplinary surgical approach. Long-term survival can be achieved for patients without proven metastases.

\section{Acknowledges:}

The authors declare that there is no conflict of interest. The authors received no specific grant from any funding agency in the public, commercial, or not-for-profit sectors.

\section{REFERENCES}

1. Jemal A, Siegel R, Ward E, Hao Y, Xu J, Murray T, et al. Cancer statistics, 2008. CA: a cancer journal for clinicians. 2008;58(2):71-96.

2. Bissada NK, Yakout HH, Babanouri A, Elsalamony T, Fahmy W, Gunham M, et al. Long-term experience with management of renal cell carcinoma involving the inferior vena cava. Urology. 2003;61(1):89-92.

3. Kulkarni J, Jadhav Y, Valsangkar RS. IVC Thrombectomy in Renal Cell Carcinoma-Analysis of Out Come Data of 100 Patients and Review of Literature. Indian journal of surgical oncology. 2012;3(2):107-13. 
4. Al Otaibi M, Youssif TA, Alkhaldi A, Sircar K, Kassouf W, Aprikian A, et al. Renal cell carcinoma with inferior vena caval extention: impact of tumour extent on surgical outcome. BJU International. 2009;104(10): 1467-70.

5. Parra J, Drouin SJ, Hupertan V, Comperat E, Bitker $\mathrm{MO}$, Rouprêt M. Oncological outcomes in patients undergoing radical nephrectomy and vena cava thrombectomy for renal cell carcinoma with venous extension: a single-centre experience. European journal of surgical oncology : the journal of the European Society of Surgical Oncology and the British Association of Surgical Oncology. 2011;37(5):422-8.

6. Ali ASM, Vasdev N, Shanmuganathan S, Paez E, Dark $\mathrm{JH}$, Manas D, et al. The surgical management and prognosis of renal cell cancer with IVC tumor thrombus: 15-Years of experience using a multi-specialty approach at a single UK referral center. Urologic Oncology: Seminars and Original Investigations. 2013;31(7): 1298-304.

7. Ciancio G, Manoharan M, Katkoori D, De Los Santos $\mathrm{R}$, Soloway MS. Long-term survival in patients undergoing radical nephrectomy and inferior vena cava thrombectomy: single-center experience. European urology. 2010;57(4):667-72.

8. Reese AC, Whitson JM, Meng MV. Natural history of untreated renal cell carcinoma with venous tumor thrombus. Urologic oncology. 2013;31(7):1305-9.

9. Blute ML, Leibovich BC, Lohse CM, Cheville JC, Zincke H. The Mayo Clinic experience with surgical management, complications and outcome for patients with renal cell carcinoma and venous tumour thrombus. BJU Int. 2004;94(1):33-41.

10. Ebbing J, Wiebach T, Kempkensteffen C, Miller K, Bachmann A, Günzel K, et al. Evaluation of perioperative complications in open and laparoscopic surgery for renal cell cancer with tumor thrombus involvement using the Clavien-Dindo classification. European journal of surgical oncology : the journal of the European Society of Surgical Oncology and the British Association of Surgical Oncology. 2015;41(7):941-52.

11. Lardas M, Stewart F, Scrimgeour D, Hofmann F, Marconi L, Dabestani S, et al. Systematic Review of Surgical Management of Nonmetastatic Renal Cell Carcinoma with Vena Caval Thrombus. European urology. 2016;70(2):265-80.

12. Sosa RE, Muecke EC, Vaughan ED, Jr., McCarron JP, Jr. Renal cell carcinoma extending into the inferior vena cava: the prognostic significance of the level of vena caval involvement. The Journal of urology. 1984; 132(6):1097-100.

13. Wagner B, Patard JJ, Méjean A, Bensalah K, Verhoest G, Zigeuner R, et al. Prognostic value of renal vein and inferior vena cava involvement in renal cell carcinoma. European urology. 2009;55(2):452-9.

14. Marshall FF, Reitz BA, Diamond DA. A new technique for management of renal cell carcinoma involving the right atrium: hypothermia and cardiac arrest. The Journal of urology. 1984;131(1):103-7.

15. Murphy GJ, Angelini GD. Side effects of cardiopulmonary bypass: what is the reality? Journal of cardiac surgery. 2004;19(6):481-8.

16. Wang B, Huang Q, Liu K, Fan Y, Peng C, Gu L, et al. Robot-assisted Level III-IV Inferior Vena Cava Thrombectomy: Initial Series with Step-by-step Procedures and 1-yr Outcomes. European urology. 2020;78(1): 77-86.

17. Patel HD, Puligandla M, Shuch BM, Leibovich BC, Kapoor A, Master VA, et al. The future of perioperative therapy in advanced renal cell carcinoma: how can we PROSPER? Future Oncol. 2019;15(15):1683-95.

\title{
Sažetak
}

\section{MULTIDISCIPLINARNO KIRURŠKO LIJEČENJE BUBREŽNOG KARCINOMA SVIJETLIH STANICA SA TUMORSKIM TROMBOM DONJE ŠUPLJE VENE RAZINE III I IV: NAŠE ISKUSTVO U PROTEKLOM DESETLJEĆU}

\author{
T. Hudolin, V. Ferenčak, L. Penezić, T. Zekulić, T. Kuliš, M. Marić, O. Pavlović, A. El-Saleh, \\ N. Knežević, E. Goluža, B. Biočina i Ž. Kaštelan
}

Pacijenti sa nemetastatskim, svijetlostaničnim karcinomom bubrega stadija T3, predstavljaju klinički izazov za urologe. Doseg tumorskog tromba unutar donje šuplje vene je glavna odrednica složenosti krurškog zahvata. Tumorski trombi razine III i IV zahtijevaju upotrebu kardiopulmonalnog premoštenja I hipotermijskog aresta. Pažljiva preoperativna procjena i multidisciplinarni pristup je neophodan. U našem centru je liječeno 12 pacijenata sa svijetlostaničnim karcinomom bubrega i tumorskim trombom u donjoj šupljoj veni. Ukupno preživljenje nakon 29 mjeseci je za ove pacijente bilo $69 \%$. U ovom trenutku, od 9 preživjelih pacijenata, 6 je bez recidiva bolesti, a 3 imaju progresiju. U našoj studiji smo pokazali da pažljivo izabrani pacijenti sa svijetlostaničnim karcinomom bubrega i tumorskim trombom razine III i IV mogu biti izliječeni agresivnim kirurškim pristupom.

KLJUČNE RIJEČI: karcinom bubrežnih stanica, donja šuplja vena, venska tromboza, radikalna nefrektomija, izvantjelesna cirkulacija 